\title{
New Archaeological Discoveries in The Geological Formations and Heritages along the Ba River Ancient Valley
}

\author{
La The Phuc ${ }^{1}$, Luong Thi Tuat ${ }^{1 *}$, Bui Van Thom ${ }^{2}$, Nguyen Khac $\mathrm{Su}^{3}$, \\ Vu Tien Duc ${ }^{4}$, Bui Quang Anh $^{1}$, Nguyen Trung Minh ${ }^{1}$, Dang Thi Hai Yen ${ }^{1}$ \\ ${ }^{1}$ Vietnam National Museum of Nature, Vietnam Academy of Science and Technology, \\ 18 Hoang Quoc Viet, Ha Noi, Vietnam \\ ${ }^{2}$ Institute of Geological Sciences, Vietnam Academy of Science and Technology, \\ 84 Chua Lang, Dong Da, Hanoi, Vietnam \\ ${ }^{3}$ Vietnam Archaeological Association, 61 Phan Chu Trinh, Hoan Kiem, Hanoi, Vietnam \\ ${ }^{4}$ Institute of Social Sciences of Central Highlands, 1 A Nguyen Van Linh, Buon Ma Thuot, Dak Lak, Vietnam
}

Received 28 April 2020

Revised 08 September 2020; Accepted 14 September 2020

\begin{abstract}
In dry season of 2019, a series of new mix-heritages containing both of natural/geological and prehistoric archaeological values were discovered along the Ba river ancient valley by the field survey team of the project TN17/T06. The archaeological relics were uncovered right in the geological heritage sites such as: waterfalls, fossil sites, ancient terraces, and low mountain slopes along the Ba river ancient valley, which belong to eluvial, deluvial, proluvial and alluvial formations of Pleistocene age. Hundreds of stone tools, including dozens of petrified wood tools were collected, such as: uni-facial and bi-facial tools, end-chooper, side-chopper, scraper, spearhead tool, flake and core tools, etc. The materials of the tools were made of quartz, quartzite, siliceous stone, opalchalcedony, petrified wood and basalt, which were recognized as geological heritages (A type: Paleontology; D type: Rock; F type: Minerals, according to the classification in the Circular 50/2017-TT-BTNMT of MONRE) of the heritage region. The collected artifacts characterise technique and geometric shape types of Paleolithic age. The archaeological discoveried sites were highly evaluated by Vietnamese and foreign archaeologists because they play a great important role in studying Paleolithic stage in Gia Lai province and The Central Highlands particularly, and in Vietnam and Southeast Asia generally. Besides, they have increased comprihensive heritage values of the region, as well as provided double invaluable resources (both natural and cultural heritage) for tourism exploitation and socio-economic sustainable development.
\end{abstract}

Keywords: heritage; archaeological site, stone tool, Ba river.

\footnotetext{
* Corresponding author.

E-mail address: t_luongthi@yahoo.com.vn

https://doi.org/10.25073/2588-1094/vnuees.4621
} 


\title{
Một số phát hiện mới về di tích khảo cổ trong các thành tạo và di sản địa chất dọc thung lũng cổ sông $\mathrm{Ba}$
}

\author{
La Thế Phúc ${ }^{1}$, Lương Thị Tuất ${ }^{1 *}$, Bùi Văn Thơm², Nguyễn Khắc Sử ${ }^{3}$, \\ Vũ Tiến Đức ${ }^{4}$, Bùi Quang Anh ${ }^{1}$, Nguyễn Trung Minh ${ }^{1}$, Đặng Thị Hải Yến ${ }^{1}$ \\ ${ }^{1}$ Bảo tàng Thiên nhiên Việt Nam, Viện Hàn lâm Khoa học và Công nghệ Việt Nam, \\ 18 Hoàng Quốc Việt, Hà Nội, Việt Nam \\ ${ }^{2}$ Viện Địa chất, Viện Hàn lâm Khoa học và Công nghệ Việt Nam, 84 Chùa Láng, Đống Đa, Hà Nội, Việt Nam \\ ${ }^{3}$ Hội Khảo cổ học, 61 Phan Chu Trinh, Hoàn Kiếm, Hà Nội, Việt Nam \\ ${ }^{4}$ Viện Khoa học xã hội vùng Tây Nguyên, 1 A Nguyễn Văn Linh, Buôn Ma Thuột, Đắk Lắk, Việt Nam \\ Nhận ngày 28 tháng 4 năm 2020 \\ Chỉnh sửa ngày 08 tháng 9 năm 2020; Chấp nhận đăng ngày 14 tháng 9 năm 2020
}

\begin{abstract}
Tóm tắt: Mùa khô năm 2019, đoàn khảo sát thực địa của đề tài TN17/T06 đã phát hiện hàng loạt di sản kép, chứa đồng thời cả hai giá trị di sản địa chất và khảo cổ tiền sử, dọc thung lũng cổ sông Ba. Các di tích khảo cổ được tìm thấy ngay tại các điểm di sản địa chất như các thác nước, các điểm hóa thạch, các thềm sông cổ và trên các sườn núi thấp dọc thung lũng cổ sông $B a$, thuộc các thành tạo eluvi, deluvi, proluvi và aluvi tuổi Pleistocen. Hàng trăm công cụ đá, trong đó có hàng chục công cụ chế tác từ gỗ hóa thạch đã được sưu tầm, bao gồm: công cụ ghè một mặt và ghè hai mặt, công cụ chặt thô rìa dọc, côn cụ chặt thô rìa ngang, công cụ nạo, công cụ mũi nhọn, công cụ mảnh tước và công cụ hạch, v.v. Chất liệu các công cụ làm từ thạch anh, quartzit, đá silic, opal-chalcedon, đá sừng, gỗ hóa thạch và đá basalt, cũng chính là những loại đá đã được xác lập là di sản địa chất (kiểu ACổ sinh, kiểu D- Đá, kiểu F- Khoáng vật, khoáng sản theo phân loại di sản địa chất quy định trong Thông tư số 50/2017/TT BTNMT của Bộ Tài nguyên Môi trường) có giá trị của khu vực di sản. Đặc trưng kỹ nghệ và kiểu dáng của các công cụ đá sưu tầm được tiêu biểu cho thời đại Đá cũ. Những phát hiện khảo cổ mới này đã được các chuyên gia khảo cổ trong nước và quốc tế đánh giá rất cao, vì đã bổ sung nguồn tư liệu khảo cổ rất có giá trị để nghiên cứu giai đoạn tiền sử Đá cũ ở tỉnh Gia Lai, Tây Nguyên nói riêng và ở Việt Nam, Đông Nam Á nói chung, đồng thời nâng cao giá trị tổng thể về di sản của khu vực và cung cấp nguồn tài nguyên di sản kép (di sản thiên nhiên và di sản văn hóa) quý giá cho khai thác du lịch và phát triển bền vững kinh tế xã hội.
\end{abstract}

Tù khóa: di sản, di tích khảo cổ, công cụ đá, sông Ba.

\section{Mở đầu}

Đới đứt gãy Sông Ba có vị trí đặc biệt trong cấu trúc địa chất khu vực Nam Trung Bộ $[1,2]$. Đây là một đới đứt gãy lớn dạng địa hào, còn ẩn chứa nhiều thông tin quan trọng về lịch sử phát triển địa chất cũng như lịch sử phát triển của tự nhiên và con người trong khu vực. Sông Ba phát triển dọc theo đới đứt gãy này, có lưu vực thuộc các tỉnh Kon Tum, Gia Lai, một phần nhỏ phía đông bắc của tỉnh Đắk Lắk và một phần nhỏ phía nam của tỉnh Phú Yên (Hình 1). Khu vực thung

\footnotetext{
* Tác giả liên hệ.

Địa chỉemail: t_luongthi@yahoo.com.vn

https://doi.org/10.25073/2588-1094/vnuees.4621
} 
lũng sông $B a$ rất phong phú các di sản thiên nhiên, nhiều vườn quốc gia, khu bảo tồn thiên nhiên có tính đa dạng sinh học cao, nhiều di sản địa chất có giá trị nổi bật như các thác nước, núi lửa và các di sản địa chất liên quan với hoạt động núi lửa, gỗ hóa thạch,... đã được điều tra nghiên cứu xác lập và bảo tồn phục vụ khai thác du lịch [3-5]. Về khảo cổ, có gần 100 di tích khảo cổ tiền sử đã được phát hiện [6-8], trong đó một số di tích đã được khai quật, chủ yếu thuộc thời kỳ Đá mới, chỉ có một cụm di tích duy nhất ở An Khê thuộc Sơ kỳ Đá cũ [8-11].

Thực hiện đề tài TN17/T06 do Bảo tàng Thiên nhiên Việt Nam chủ trì (thuộc Chương trình Tây Nguyên giai đoạn 2016-2020), trong đợt công tác từ tháng 3-5/2019, đoàn khảo sát địa chất do La Thế Phúc cùng các cộng sự đã phát hiện nhiều dấu hiệu khảo cổ tiền sử tại các điểm di sản địa chất (DSĐC). Cụ thể gồm: các di vật là mảnh tước, bàn mài, hạch đá và mảnh gốm có mật độ khá dày ở DSĐC thác Hang Dơi, thuộc thị trấn K'Bang (Gia Lai); các mảnh gốm tiền sử ở DSĐC núi lửa Biển Hồ, Pleiku (Gia Lai); các công cụ đá, mảnh tước, hạch đá ở DSĐC cổ sinh Chư A Thai, huyện Phú Thiện [5]; các mảnh gốm tiền sử ở thềm basalt Phú Xuân, huyện Krông Năng (Đắk Lắk), ...

Trong đợt công tác từ tháng 11 đến 12/2019, đoàn khảo sát của đề tài lại tiếp tục phát hiện thêm một số biểu hiện di tích tiền sử, gồm: các công cụ, mảnh tước, hạch đá ở thềm sông cổ thuộc xã Ea Kly, huyện Krông Pắk (Đắk Lắk); các công cụ, mảnh tước, hòn ghè, hạch đá, đá nguyên liệu ở các thềm sông cổ thuộc các xã Ia R'Mok và Ia H'Dreh, huyện Krông Pa; phường Cheo Reo, thị xã A Yun Pa; xã Pờ Tó, huyện Ia $\mathrm{Pa}$; ở DSĐC Thác 50 trong khu Bảo tồn Thiên nhiên Kon Chư Răng, thuộc xã Sơn Lang huyện K'Bang (tỉnh Gia Lai).

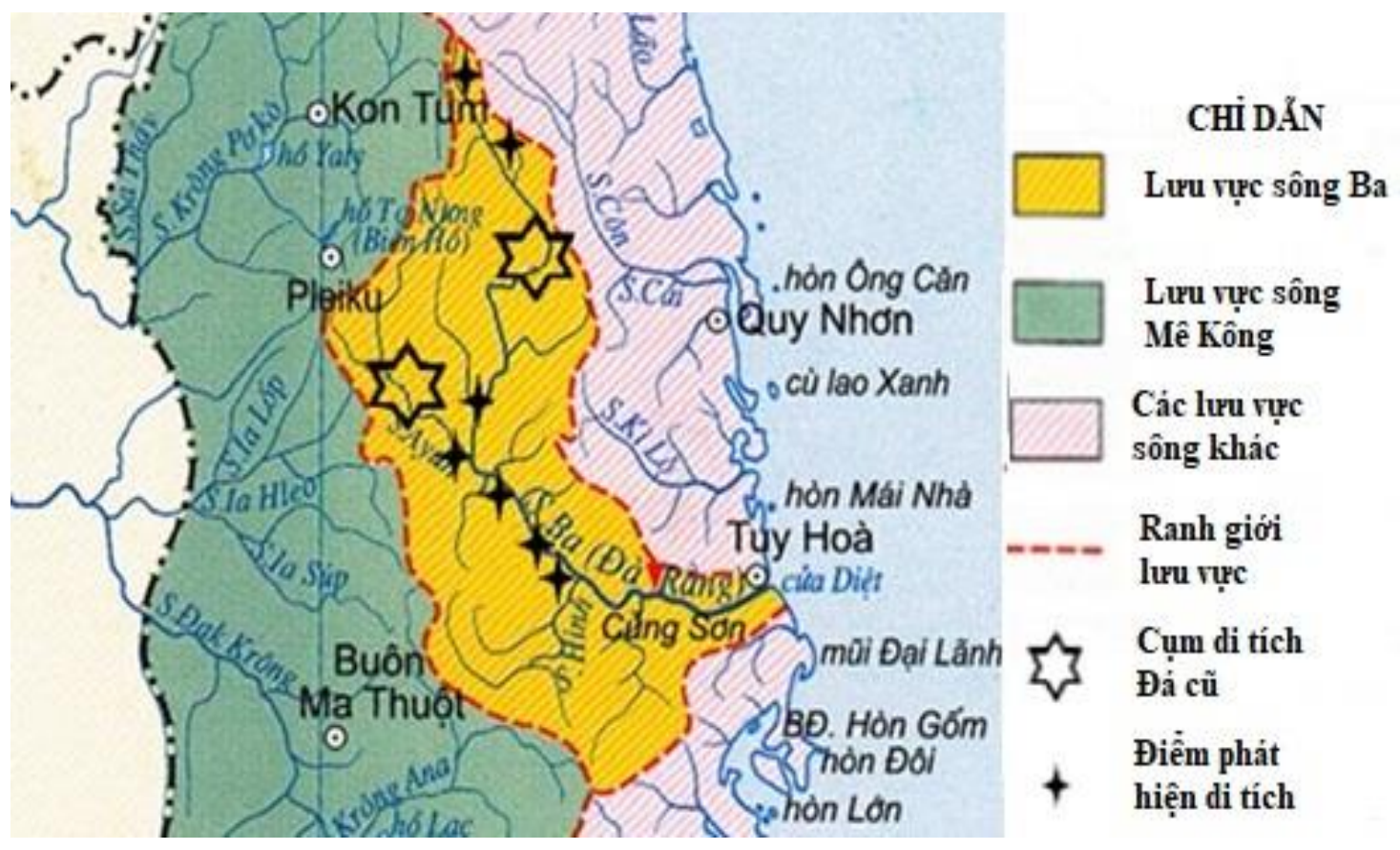

Hình 1. Sơ đồ phân bố các điểm và cụm điểm di tích Đá cũ khu vực thung lũng cổ sông Ba (thành lập trên cơ sở "Bản đồ sông ngòi Việt Nam" từ bandovietnam.maytinhhtl.com). 


\section{Phương pháp nghiên cứu}

\subsection{Phưong pháp viễn thám}

Đây là phương pháp rất hiệu quả cho việc khoanh định dự báo các biểu hiện địa chất lý thú về địa hình địa mạo, miệng núi lửa, hang động núi lửa, hồ nước và thác nước. Các tác giả đã tổng hợp kế thừa và phân tích, giải đoán các ảnh viễn thám (ảnh vệ tinh landsat, spots có độ phân dải từ $2,5 \mathrm{~m}$ đến $30 \mathrm{~m}$, ảnh máy bay, google map). Trên cơ sở kết hợp tài liệu viễn thám với các tài liệu bản đồ địa chất tỷ lệ $1 / 200.000$ và bản đồ địa hình (tỷ lệ $1 / 50.000$ của Chương trình Tây Nguyên), các biểu hiện địa chất lý thú thuộc kiểu địa mạo được đánh dấu trên bản đồ, làm cơ sở định hướng cho các lộ trình thực địa tìm kiếm và xác lập di sản.

\subsection{Phuơng pháp điều tra xã hội học}

Phương pháp này được sử dụng để thu thập từ cộng đồng (đặc biệt là cộng đồng người bản địa) những thông tin liên quan đến các biểu hiện di sản địa chất lý thú trong vùng nghiên cứu. Các tác giả đã tiến hành thu thập thông tin bằng cách phỏng vấn người dân, điền thông tin thu thập được vào các phiếu điều tra và thuê người được phỏng vấn trực tiếp dẫn đường đến các khu vực được dự đoán có tiềm năng di sản cần điều tra, tìm kiếm. Kết hợp với những định hướng ban đầu, phương pháp này tỏ ra rất hiệu quả trong quá trình khảo sát thực địa điều tra, tìm kiếm và xác lập di sản ở Tây Nguyên.

\subsection{Phuoong pháp khảo sát thực địa, thu thâp tài liệu nguyên thưy}

Công tác khảo sát thực địa đã được tiến hành theo 2 cấp độ: khảo sát sơ bộ và khảo sát chi tiết. Khảo sát sơ bộ được tiến hành trước tiên trên diện rộng để lựa chọn/khoanh định các vùng cần tập trung cho khảo sát điều tra chi tiết. Khảo sát điều tra chi tiết được định hướng và tiến hành trên cơ sở kết quả khảo sát sơ bộ để thu thập chi tiết tài liệu nguyên thuỷ cho các lĩnh vực chuyên môn (địa chất, sinh học, văn hóa); đánh giá hiện trạng di sản, các yếu tố xâm hại di sản và hiện trạng bảo tồn di sản; quay phim chụp ảnh, xác lập tổng thể các giá trị di sản,... làm cơ sở khoa học để xây dựng hồ sơ di sản; đánh giá, phân loại, xếp hạng di sản và đề xuất các giải pháp bảo tồn, quản lý và khai thác phát triển bền vững.

\subsection{Phương pháp thống kê, phân loại hiện vật} và di sản

Kết quả điều tra, khảo sát thực địa sẽ được hiệu chỉnh và thẩm định tính xác thực, thống kê phân loại và hệ thống hóa các hiện vật và di sản trong vùng nghiên cứu. Nội dung phân loại di sản được thể hiện theo 2 góc độ: phân loại học và phân loại xếp hạng. Đối với phân loại học: trên cơ sở các tài liệu thu thập, tổng hợp, khảo sát điều tra thực địa; hiện vật, di sản, trong vùng nghiên cứu đã được xác lập, thống kê phân loại theo các quy định chuyên ngành của từng thể loại di sản. Với mỗi loại di sản của mỗi lĩnh vực (địa chất, sinh vật, văn hóa) sẽ dựa trên phương thức phân loại khác nhau. Các mẫu vật, đặc biệt là hiện vật khảo cổ của đề tài được các chuyên gia khảo cổ có trình độ chuyên môn cao và sâu hiệu chỉnh, mô tả, thống kê phân loại theo quy định chuyên ngành. Đối với phân loại xếp hạng di sản sẽ được tiến thành theo các tiêu chí riêng biệt của từng loại hình di sản, không thuộc phạm vi của bài viết này.

\section{Kết quả phát hiện mới}

\subsection{Phát hiện di vật ở DSĐC Thác 50, Khu Bảo tồn Thiên nhiên Kon Chu Răng}

* Khảo sát phát hiện di tích. Sau 2 đợt thực địa (năm 2018 - 2019) không thể tiếp cận được Thác 50 vì lý do thời tiết; lần thứ 3 vào tháng 12/2019, nhờ sự hỗ trợ đắc lực của các cán bộ Khu Bảo tồn Thiên nhiên Kon Chư Răng, đoàn khảo sát địa chất của đề tài TN17/T06 đã tiếp cận được Thác 50 để khảo sát đánh giá các giá trị di sản của thác. Tại đây, La Thế Phúc và các cộng sự đã phát hiện được một số di vật của người tiền sử.

* So luợc đặc điểm địa chất của di tích. Thác 50 là một DSĐC (phụ kiểu B1: cảnh quan địa mạo), có tọa độ $14^{0} 31^{\prime} 5.4^{\prime \prime}$ vĩ độ Bắc; $108^{0}$ 
36' 24.5" kinh độ Đông, nằm trong Khu Bảo tồn Thiên nhiên Kon Chư Răng, thuộc địa phận xã Sơn Lang, huyện K'Bang, tỉnh Gia Lai. Thác có độ cao $54 \mathrm{~m}$, rộng $20-100 \mathrm{~m}$ tùy theo mùa (Hình 2a). Mặt thác thẳng đứng, đá dưới chân thác bị phá hủy lõm vào thành một hàm ếch lớn (Hình $2 \mathrm{a} ; 2 \mathrm{~b})$ là môi trường sống của một số loài động vật như chim én, dơi và rắn (Hình $2 \mathrm{c}$ ). Nước chảy qua mặt thác, đổ xuống chân thác tạo thành hồ có độ sâu $>10 \mathrm{~m}$ nước với nhiều hang hốc lớn. Suối chảy qua Thác 50 , đổ về phía Nam, chảy ra dòng suối lớn thuộc hệ thống sông $\mathrm{Ba}$. Toàn bộ lưu vực thác nằm trên diện phân bố đá basalt màu xám - xám đen, cấu tạo khối đặc sít hoặc lỗ hổng, kiến trúc porphyr với nền ophit, dolerit hoặc gian phiến; được xếp vào hệ tầng Đại $\mathrm{Nga}\left(\beta \mathrm{N}_{2} d n\right)$; tuổi khoảng 5,3-2,58 triệu năm BP [2]. Phần mái của hàm ếch cấu tạo bởi đá basalt đặc xít, rắn chắc; ngay tại hàm ếch là basalt lỗ hổng, xốp, dễ bị phong hóa mềm bở. Các hòn đá vẫn còn góc cạnh (Hình $2 \mathrm{~d}$ ), cấu tạo đặc xít, là đá vỡ từ phần trên mái hàm ếch rơi xuống. Do có đặc điểm rắn chắc, vỡ sắc cạnh và dễ tạo hình theo mọi hướng nên cư dân tiền sử nơi đây đã dùng đá basalt làm nguyên liệu để chế tác công cụ, phục vụ cuộc sống sinh tồn. Các di vật thu được ở Thác 50 gồm: 01 công cụ nạo (Hình $2 \mathrm{~d}$ ), 02 công cụ mũi nhọn (Hình 2e, 2f), mảnh tước (Hình $2 \mathrm{~g}$ ), tất cả đều được làm từ đá basalt. Với cảnh quan đẹp và quy mồ lớn, Thác 50 là một trong số ngọn thác đẹp nhất Tây Nguyên, hiện còn rất hoang sơ, ít người có thể tiếp cận được do đường đi vào thác rất khó khăn nguy hiểm, rắn (Hình $2 \mathrm{c}$ ) và vắt rất nhiều; đoàn khảo sát của đề tài do không đủ các trang thiết bị cần thiết đảm bảo an toàn nên không thể ở lại qua đêm để khảo sát kỹ hơn. Vì vậy, việc khảo sát các giá trị khảo cổ ở Thác 50 mới chỉ dừng lại ở mức sơ bộ, khẳng định được sự hiện diện của người tiền sử ở khu vực này và rất cần điều tra nghiên cứu chi tiết hơn để làm tăng giá trị di sản hỗn hợp của Thác 50 cũng như của cả Khu Bảo tồn Thiên nhiên Kon Chư Răng.

Từ Thác 50, dọc theo phía hạ lưu, qua thị trấn K'Bang, tới thung lũng An Khê là cụm di tích Đá cũ An Khê nổi tiếng đã được Viện Khảo cổ học (Viện Hàn lâm Khoa học xã hội Việt Nam) phối hợp với Viện Khảo cổ và Dân tộc học Novosibirsk (Viện Hàn lâm Khoa học Liên bang Nga) khai quật và công bố kết quả [8,9,11].
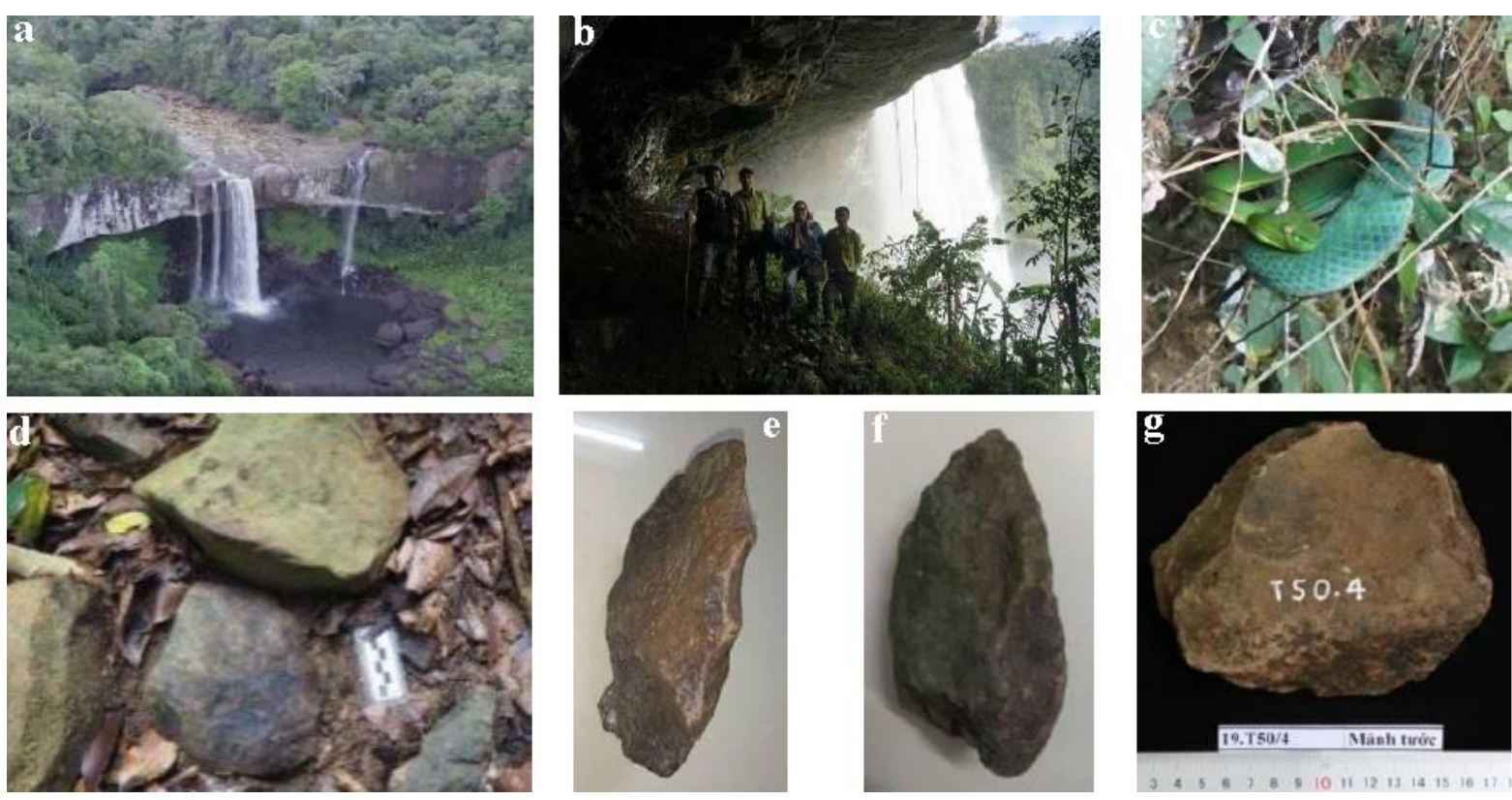

Hình 2. Cảnh quan $(\mathrm{a}, \mathrm{b})$, rắn $(\mathrm{c})$, và hiện vật khảo cổ $(\mathrm{d}, \mathrm{e}, \mathrm{f}, \mathrm{g})$ tại Thác 50. 


\subsection{Phát hiện di vật trên thềm sông cổ bậc 3 (DSĐC phụ kiểu B1) ở xã Pò̀ Tó, huyện Ia Pa}

* Khảo sát phát hiện di tích: Tháng 1112/2019, khi tiến hành khảo sát thực địa phần phía đông tỉnh Gia Lai, đoàn khảo sát địa chất của đề tài TN17/T06 đã dừng chân ven đường Trường Sơn Đông để quan sát các hố khai thác vật liệu san nền. Dựa theo các dấu hiệu tìm kiếm đã được xác lập ở khu vực Chư A Thai, đoàn đã phát hiện được một số di vật công cụ đá tiền sử (Hình 3b; 3c; 3d; 3e).

* So lược đặc điểm địa chất tầng chứa di vật: Các di vật được phát hiện trên đồi trồng sắn, nằm sát đường Trường Sơn Đông, thuộc xã Pờ Tó, huyện Ia $\mathrm{Pa}$, có tọa độ $13^{0} 39^{\prime} 36.7^{\prime \prime}$ vĩ độ Bắc, $108^{0} 24^{\prime} 21.1^{\prime \prime}$ kinh độ Đông. Khảo sát sơ bộ cho thấy dải đồi này có thể thuộc thềm cổ bậc 3 của sông Ba. Phần phía Nam dải đồi này đang được đào để lấy đất san nền (Hình $3 a$ ) đã lộ ra tập đá trầm tích hỗn độn gồm cuội sạn, sỏi lẫn cát, bột, sét màu xám nhạt - trắng xám. Cuội, sạn, sỏi ở đây có thành phần thạch anh, quartzit, đá silic. Tại đây, đoàn khảo sát đã thu thập được một số di vật, gồm: hạch đá, công cụ mảnh tước và đá có vết ghè. Các di vật đều được chế tác từ các loại đá có độ cứng cao như thạch anh (Hình $3 b$; 3c; 3d) hoặc quartzit (Hình 3e). Tuy nhiên, việc phát hiện được các di vật đá ở đây mới chỉ là khám phá bước đầu, rất cần được điều tra khảo sát kỹ hơn để làm sáng tỏ giá trị khảo cổ tiền sử ở khu vực này và mở rộng cho cả khu vực thung lũng cổ sông $\mathrm{Ba}$.

\subsection{Phát hiện cưm di tích dọc thung lũng cổ sông Ea Ayun ở khu vưc Chu A Thai, Phú Thiện}

* Khảo sát phát hiện và thẩm định di tích: Trên cơ sở phân tích tài liệu từ Bản đồ địa chất tờ An Khê tỷ lệ 1/200.000 [9], Bản đồ địa hình 1/50.000 (của Chương trình Tây Nguyên), ảnh google map và một số nguồn tài liệu khác cho thấy khu vực Chư A Thai, huyện Phú Thiện có biểu hiện của 2 kiểu DSĐC: i) Các miệng núi lửa và địa hình núi lửa khu vực Chư $\mathrm{A}$ Thai (DSĐC phụ kiểu B1: Cảnh quan địa mạo); ii) Gỗ hóa thạch ở núi Chư A Thai (DSĐC Kiểu A: Cổ sinh) rất nổi tiếng của Việt Nam. Ngoài ra, khu vực này có điều kiện tự nhiên rất đặc biệt: là nơi khô nóng nhất của Tây Nguyên, đồng thời có di sản địa văn hóa Plei Ơi độc đáo, đã được công nhận là di tích lịch sử - văn hóa cấp quốc gia năm 1993. Vào ngày $17 / 4 / 2019$, đoàn khảo sát địa chất của đề tài TN17/T06 gồm La Thế Phúc, Lương Thị Tuất, Bùi Văn Thơm cùng các cộng sự lần đầu tiên đã phát hiện một số công cự đá, mảnh tước và hạch đá phân bố rải rác trên bề mặt khu vực sườn và chân núi Chư $\mathrm{A}$ Thai, huyện Phú Thiện. Núi Chư A Thai là điểm DSĐC cổ sinh nổi tiếng của Việt Nam: các thân gỗ hóa thạch đã bị silic hóa, rất đẹp, có giá trị thương mại cao. Từ ngày $27 / 4$ đến $03 / 5 / 2019$, La Thế Phúc và Vũ Tiến Đức cùng các cộng sự đã mở rộng diện điều tra, tìm kiếm (trong khuôn khổ đề tài cấp cơ sở), phát hiện thêm 14 điểm di tích phân bố rải rác trong phạm vi khoảng $100 \mathrm{~km}^{2}$, thuộc xã Chư A Thai [5].
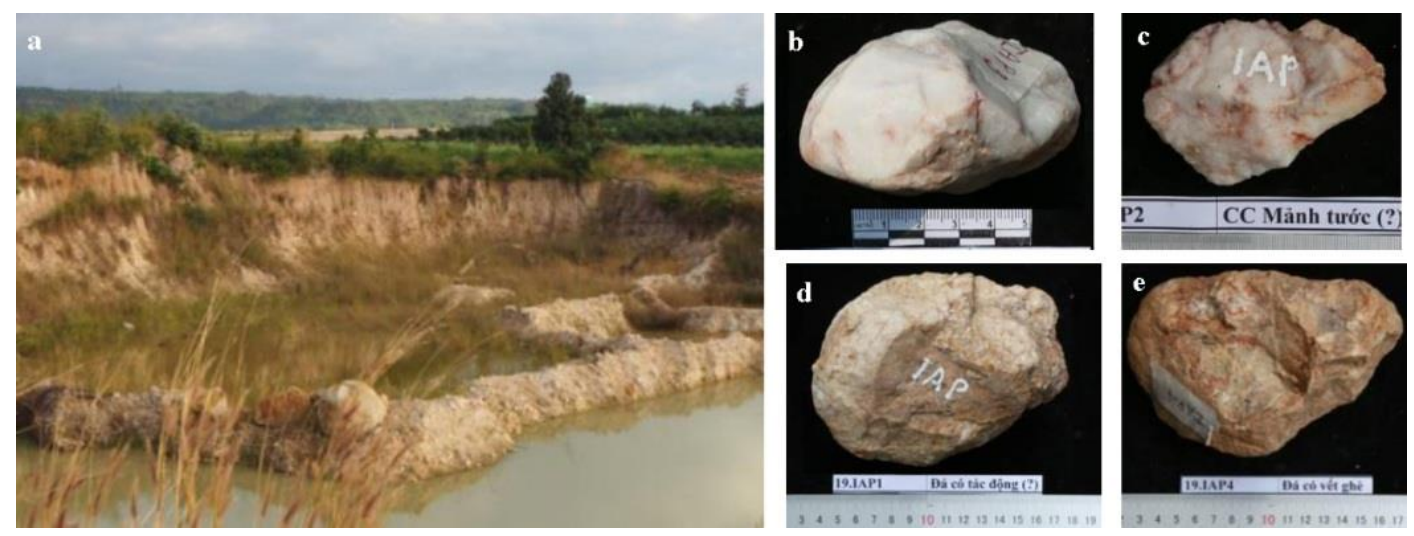

Hình 3. Cảnh quan (a) và công cụ đá (b, c, d, e) phát hiện tại thềm sông bậc 3 ở xã Pờ Tó, huyện Ia Pa. 


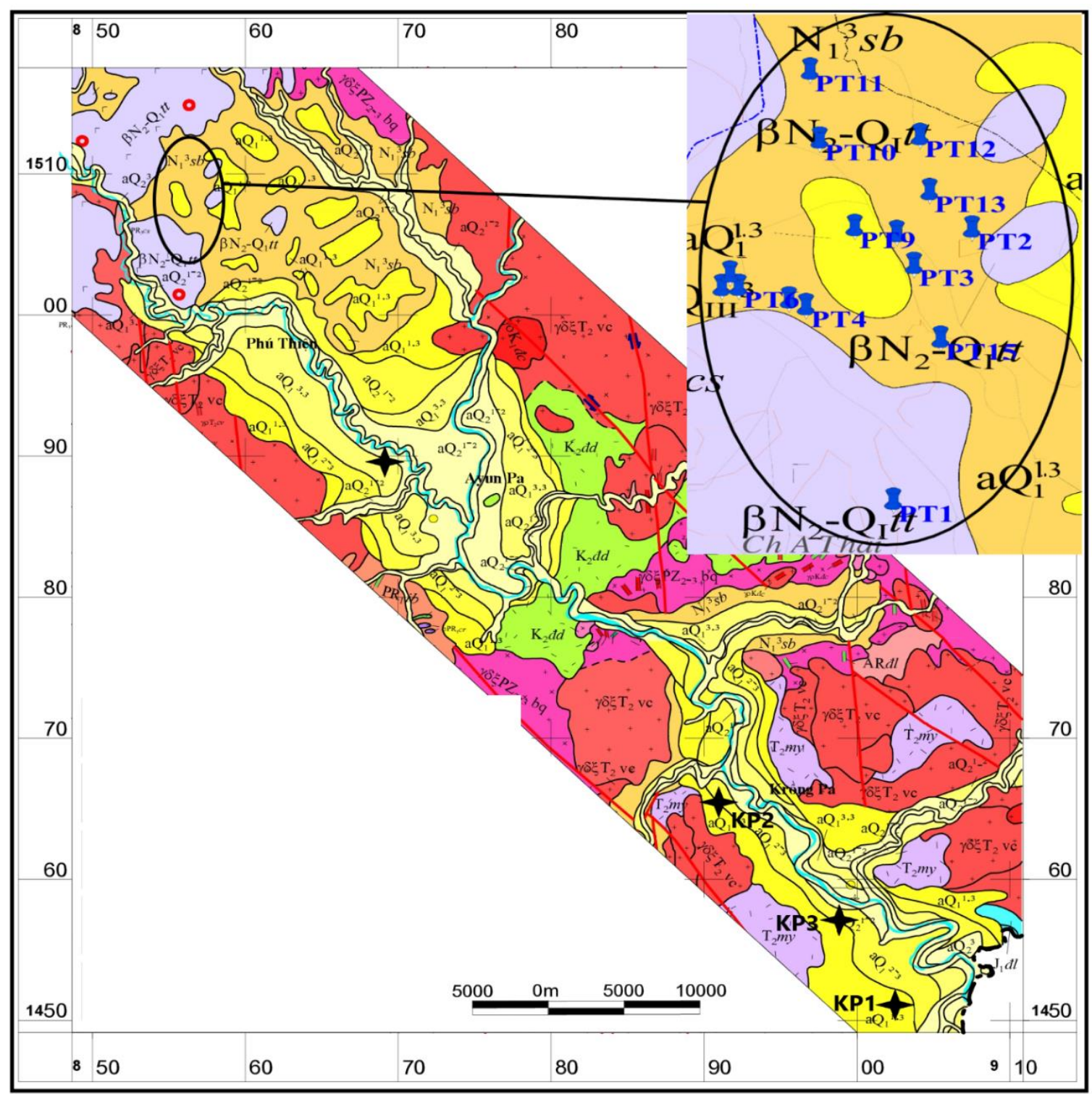

\begin{tabular}{|c|c|}
\hline $3 Q_{2}^{\prime}$ & $\begin{array}{l}\text { Holocene thượng: cuội, sỏi, } \\
\text { cát-bột, sét; dày } 1-2 \mathrm{~m}\end{array}$ \\
\hline $3 Q_{2}^{1-2}$ & $\begin{array}{l}\text { Holocene hạ - trung: cuội, sỏi, } \\
\text { sạn, cát, bột, sét; dày } 6-7 \mathrm{~m}\end{array}$ \\
\hline$a Q_{1}^{3,3}$ & $\begin{array}{l}\text { Pleistocene thượng: cuội, sỏi, } \\
\text { cát, bột, sét: dày } 7-8 \mathrm{~m}\end{array}$ \\
\hline$a Q, i^{2}$, & $\begin{array}{l}\text { Pleistocene trung - thượng: cát, } \\
\text { cuối, sỏi, bột, sét; dày } 1-2 \mathrm{~m}\end{array}$ \\
\hline$a Q_{1}^{1,3}$ & $\begin{array}{l}\text { Pleistocene ha: cuội, sỏi, sạn, } \\
\text { cát, it bột, sét; dày } 1-4 \mathrm{~m}\end{array}$ \\
\hline$\beta \mathrm{N}_{z}-Q_{i} t t$ & $\begin{array}{l}\text { Hệ tấng Túc Trưng: basalt } \\
\text { olivin, basalt pyroxen }\end{array}$ \\
\hline
\end{tabular}
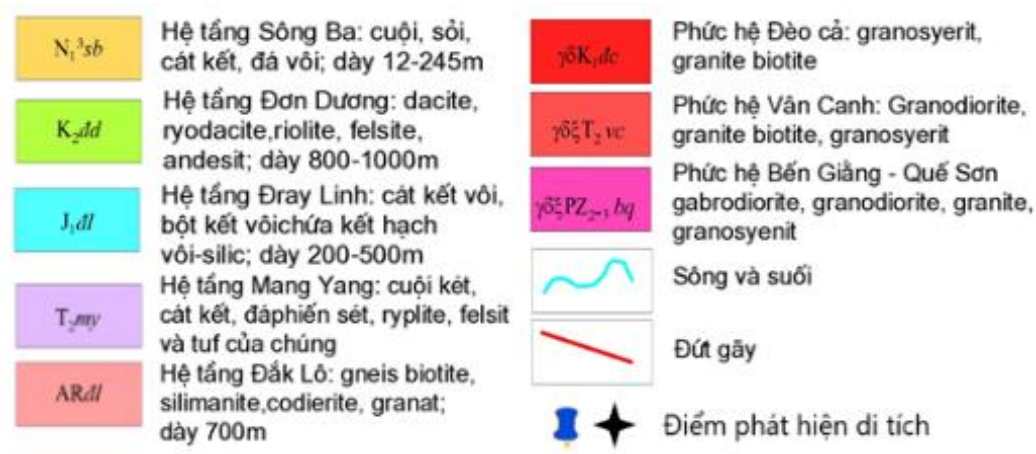

Hình 4. Sơ đồ địa chất khu vực thung lũng cổ sông Ba, phần phía Nam tỉnh Gia Lai. 
Đầu tháng 3/2020, đoàn cán bộ khoa học liên cơ quan gồm: Viện Khảo cổ học thuộc Viện Hàn lâm Khoa học Xã hội Việt Nam, Bảo tàng Thiên nhiên Việt Nam thuộc Viện Hàn lâm Khoa học \& Công nghệ Việt Nam, Viện khảo cổ và Dân tộc học Novosibirsk thuộc Viện Hàn lâm Khoa học Liên bang Nga, Sở Văn hóa Thể thao và Du lịch tỉnh Gia Lai và Ủy ban Nhân dân huyện Phú Thiện (tỉnh Gia Lai) đã phối hợp khảo sát thẩm định di tích (Hình 5a; 5b), xây dựng kế hoạch nghiên cứu tiếp theo. Kết quả chuyến khảo sát thẩm định đã lựa chọn được các vị trí khai quật cho kế hoạch hợp tác dự định sẽ triển khai từ tháng 3/2021.

* So lược đặc điểm địa chất của di tích: Thung lũng sông Ba ở khu vực phía Đông Nam của tỉnh Gia Lai, kéo dài theo hướng Tây Bắc Đông Nam qua các huyện thị: Phú Thiện - A Yun Pa - Krông Pa. Thung lũng Phú Thiện thuộc nhánh sông cổ của hệ thống sông Ba trước kia, nay được gọi là sông Ea Ayun. Sông này hợp lưu với sông $\mathrm{Ba}$ tại thị xã $\mathrm{A}$ Yun $\mathrm{Pa}$, chảy qua huyện Krông Pa xuống Phú Yên và mang tên là sông Đà Rằng chảy ra Biển Đông.

Theo kết quả điều tra cơ bản về địa chất tỷ lệ 1/200.000 [2], các thành tạo địa chất ở cụm di tích Chư $\mathrm{A}$ Thai và lân cận khu vực huyện Phú Thiện (trong phạm vi $\sim 1.500 \mathrm{~km}^{2}$ ) khá phong phú, đa dạng và bao gồm 2 nhóm thành tạo: trước Đệ tứ và Đệ tứ.

- Nhóm thành tạo đá gốc trước Đệ tú có 11 phân vị địa chất chủ yếu, bao gồm: các hệ tầng Ia Ban $\left(\mathrm{PR}_{1} i b\right)$ : amphibolit; Chư Sê $\left(\mathrm{PR}_{3} c s\right)$ : quartzit, thạch anh - sericite; Mang Yang $\left(\mathrm{T}_{2} \mathrm{a}\right.$ $m y)$ : ryolit, felsit và tuf; Sông $\mathrm{Ba}\left(\mathrm{N}_{1}{ }^{3} s b\right)$ : cuội kết, cát sạn kết, bột sét kết và Túc Trưng $\left(\beta \mathrm{N}_{2}\right.$ $\mathrm{Q}_{1} t t$ ): basalt olivin, basalt tholeit; các phức hệ magma: Bến Giằng - Quế Sơn $\left(\gamma \delta \mathrm{PZ}_{3} b g-q s\right)$ : gabro diorit, granitoit, granit; Vân Canh $\left(\gamma \delta \mathrm{T}_{2}\right.$ $v c)$ : diorit, granodiorit, granit biotit; Cha Val $\left(\mathrm{vaT}_{2} c v\right)$ : gabrnorit, gabropyroxenit, gabrodiorit; Đèo Cả $(\gamma-\gamma \xi \mathrm{K} d c)$ : granit, granosyenit, granit biotit; Phan Rang $(\gamma E p r)$ : đá mạch granit aplit, granit porphyr và Cù Mông $(\gamma \pi \mathrm{E} \quad \mathrm{cm})$ : gabrodiabas, diabas, porphyrit [2] (Hình 4). Các thành tạo địa chất này là nguồn cung cấp vật liệu cuội sỏi cho thung lũng sông $\mathrm{Ba}$. Hầu hết cuội sỏi ở đây cấu tạo bởi các đá rắn chắc, độ cứng cao như thạch anh, quartzit, đá silic,... và chúng chính là nguồn đá nguyên liệu đã được người tiền sử lựa chon để chế tác công cụ lao động.

- Nhóm thành tạo trầm tích bở rời Đệ tú. Trầm tích Pleistocen sớm phần muộn $\left(\mathrm{aQ}_{1}{ }^{1.3}\right.$, 1,80 - 0,78 triệu năm BP) lộ khá phổ biến thành 15 diện lớn nhỏ khác nhau dạng da báo ở trung tâm thung lũng Phú Thiện [2]. Thành phần trầm tích gồm cuội sạn sỏi đa khoáng, độ mài tròn tốt - trung bình, thành phần cuội sỏi chủ yếu là: thạch anh, đá silic, quartzit, cát kết dạng quartzit, gố hóa thạch, granit, aplit, ít hơn là basalt và đá sừng. Trầm tích có nguồn gốc sông, chiều dày trầm tích dưới $3 \mathrm{~m}$ (quan sát bằng mắt thường). Các công cụ đá tiền sử đều được phát hiện nằm trong lớp cuội sỏi sạn này và có những đặc điểm tương đồng với các công cụ của cụm di tích khảo cổ An Khê. Ngoài ra, ở khu vực cụm di tích Phú Thiện còn có mặt các thành tạo trầm tích tuổi Pleistocen muộn $\left(\mathrm{Q}_{1}{ }^{3}\right.$ : 126.0 - 11.7 ngàn năm $\mathrm{BP})$ và Holocen sớm-giữa $\left(\mathrm{Q}_{2}{ }^{1-2}: 11.7\right.$ - 4.2 ngàn năm $\mathrm{BP}$ ), nguồn gốc sông (aluvi) phân bố dọc theo sông Ea Ayun. Các thành tạo trầm tích Đệ tứ không phân chia $(\mathrm{Q})$ có nguồn gốc eluvi deluvi - proluvi với thành phần chủ yếu là cuội sạn sỏi đa khoáng - ít khoáng chỉ phân bố dọc các khe suối và sườn dốc của các núi vây quanh thung lũng (Hình 4). Tại chân núi Chư A Thai cũng đã phát hiện được nhiều công cụ, hạch đá, mảnh tước,,.. trong các thành tạo Đệ tứ không phân chia này.

\section{* So lược đặc điểm di tích}

- Đặc điểm phân bố. Các di tích khảo cổ tiền sử ở Chư A Thai nói riêng, khu vực thung lũng Phú Thiện nói chung phân bố chủ yếu trên 2 nhóm địa hình: 1) Trên sườn núi tiếp giáp với thung lũng; 2) Trên bề mặt các thềm sông cổ ở thung lũng Phú Thiện. Tiêu biểu cho nhóm thứ nhất là sườn Đông núi Chư $\mathrm{A}$ Thai, các di vật phân bố rải rác trên các địa hình bậc 2 , bậc 3 , bậc 4 và bậc 5 của sườn Đông núi Chư $A$ Thai (Hình 5). Tiêu biểu cho nhóm thứ hai là các gò đồi thoải 
ở xã Chư A Thai, thuộc phần trung tâm phía Bắc thung lũng Phú Thiện. Những gò đồi này chính là tàn dư của các trầm tích aluvi cổ (thềm bậc 1 , 2,3 ) của sông Ba trước kia, tuổi Pleistocen sớm phần muộn $[2,5]$.

Các gò đồi này tuy có độ cao khác nhau, nhưng đa số có cấu tạo tương đồng với phần đỉnh khá bằng phẳng, sườn khá thoải. Quan sát tại các vách taluy có thể nhận thấy mặt cắt được chia làm 2 phần rõ rệt: phần trên là cuội sạn sỏi đa khoáng có độ mài tròn tốt - trung bình, chiều dày thường $<1 \mathrm{~m}$, thành phần chủ yểu là: thạch anh, đá silic, aplit, gneis, granit hạt nhỏ, quartzit, đá sừng, gabro, basalt, gỗ silic hóa, opal-chalcedon, thủy tinh núi lửa,...; Phần dưới là cát sạn lẫn sét bột màu xám sáng - trắng xám, độ gắn kết yếu, chiều dày $>2 \mathrm{~m}$, thành phần cát chủ yếu gồm: thạch anh, felspat, mảnh đá; bột sét chủ yếu là caolinit và có thể có montmorilonit [5].

Các di vật nằm trong phần cuội sạn đa khoáng đã được tìm thấy hầu hết trên các đồi này ở khu vực xã Chư A Thai.

Từ những đặc điểm phân bố của di vật và di tích nêu trên ở Phú Thiện, tác giả đã rút ra dấu hiệu tìm kiếm di tích khảo cổ tiền sử Đá cũ thung lũng Sông Ba là các gò đồi cuội sạn đa khoáng tuổi Pleistocen, nguồn gốc aluvi ở thung lũng và nguồn gốc eluvi, deluvi, proluvi ở rìa thung lũng có độ cao tương đối $<100 \mathrm{~m}$.

- Đặc điểm hiện vật. Hiện vật thu được gồm: công cụ đá, mảnh tước, phác vật, hạch đá, hòn ghè, đá có vết ghè và đá nguyên liệu. Các công cụ này thường có trọng lượng khá lớn, trung bình từ $0,5-1,0 \mathrm{~kg}$, lớn hơn nhiều so với các công cụ thời đại Đá mới ở Hố Tre và hang C6.1 [5,12]; tiêu biểu gồm: rìu tay; bôn tay (Hình 6b); công cụ mũi nhọn (Hình 6c); công cụ rìa ngang (Hình $7 \mathrm{a})$; công cụ - rìa xiên/dọc; công cụ hình đĩa (Hình 7b); công cụ mũi nhọn tam diện (Hình 7c); công cụ mảnh tước (Hình $7 \mathrm{~d}$ ), hạch đá và công cụ hạch (Hình 7e); hòn ghè (Hình 7f). Chất liệu công cụ là đá cuội tự nhiên tại chỗ, gồm: thạch anh, quartzit, đá silic, đá sừng, cát kết dạng quartzit, opal - chalcedon, gỗ hóa thạch (silic hóa - Hình $6 \mathrm{c}$ ) và ít hơn là đá basalt.

- Phương thức chế tác. Các công cụ được ghè đẽo thô sơ từ các hòn cuội: phần đốc (phía tay cầm) của công cụ vẫn còn nguyên vỏ cuội với độ tròn cạnh và mặt bào mòn tự nhiên, phần đối diện được ghè đẽo, tu chỉnh tạo thành các rìa/ lưỡi/mũi nhọn sử dụng (Hình $7 \mathrm{a} \rightarrow 7 \mathrm{f}$ ), đặc trưng cho tổ hợp kỹ thuật "chopper-chooping tools/picks/bi-facial-handaxes" và tương đồng với công cụ An Khê [5,7,9,11].
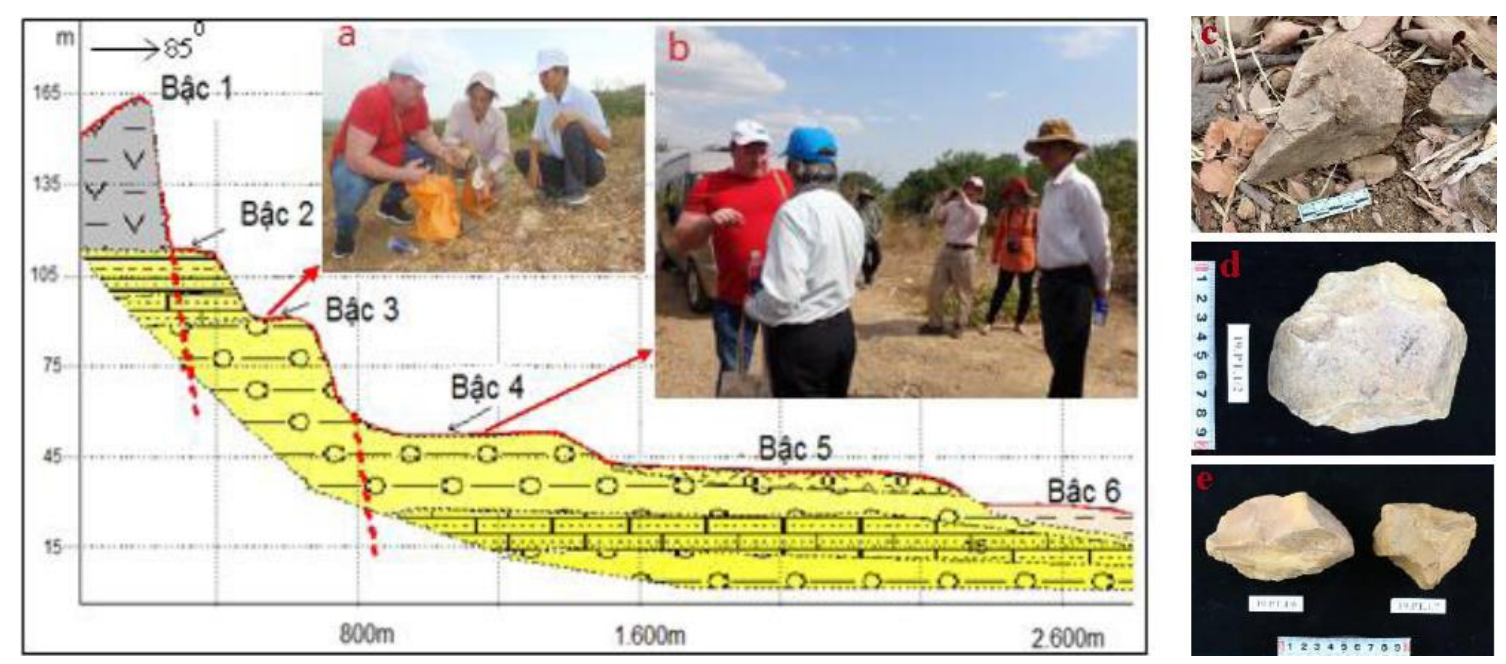

Hình 5. Sơ đồ mặt cắt địa hình sườn Đông núi Chư A Thai (Bùi Văn Thơm thành lập), a;b: Đoàn khảo sát thẩm định di tích ở địa hình bậc 3 , bậc $4 ;$ c;d;e: Một số hiện vật thu được tại địa hình bậc 3, bậc 4 (Nguồn: La Thế Phúc, 2020). 

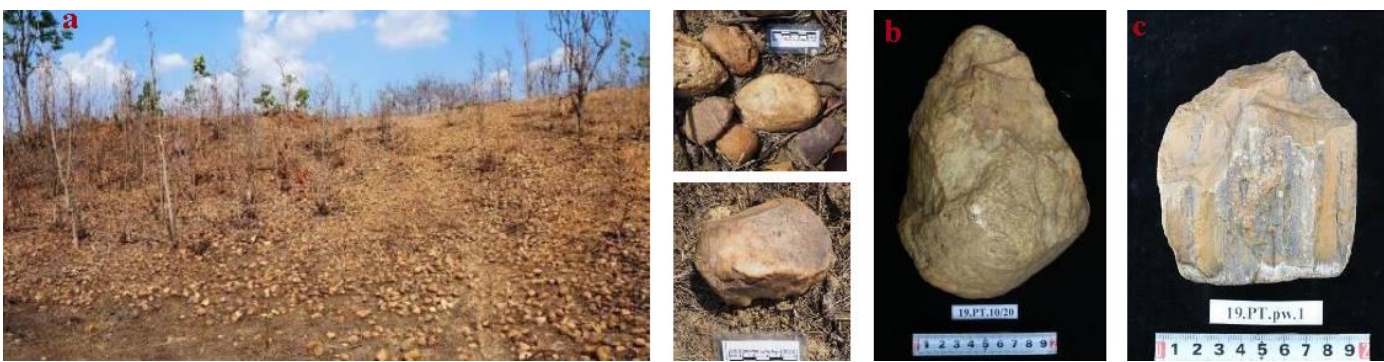

Hình 6. Gò đồi chứa hiện vật $(\mathrm{a})$ và hiện vật $(\mathrm{b}, \mathrm{c})$ ở thôn Plei Klung 1 (PT4).
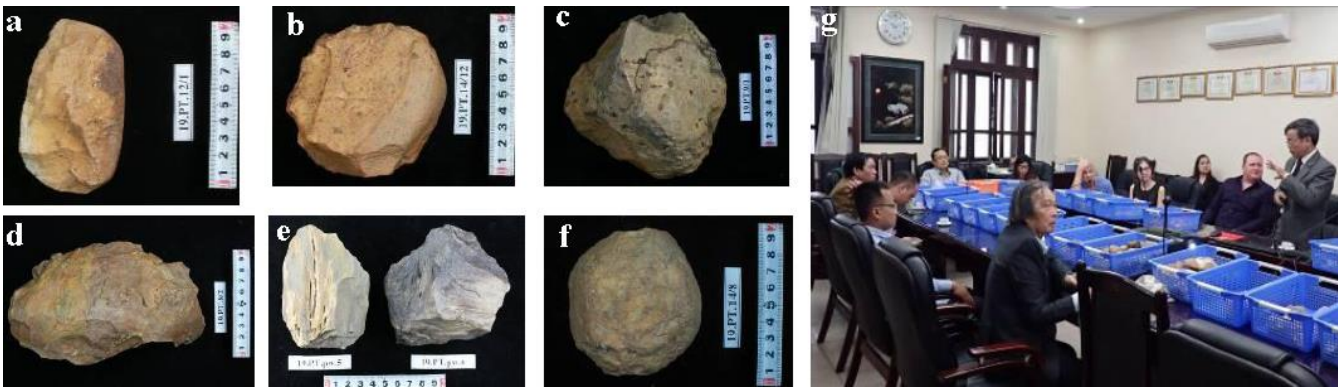

Hình 7. Các loại hình công cụ $(\mathrm{a}, \mathrm{b}, \mathrm{c}, \mathrm{d}, \mathrm{e}, \mathrm{f})$ và các chuyên gia Việt Nam và quốc tế đánh giá di vật trước khi đi thẩm định các di tích ngoài thực địa (g) (Nguồn: La Thế Phúc, 2020).
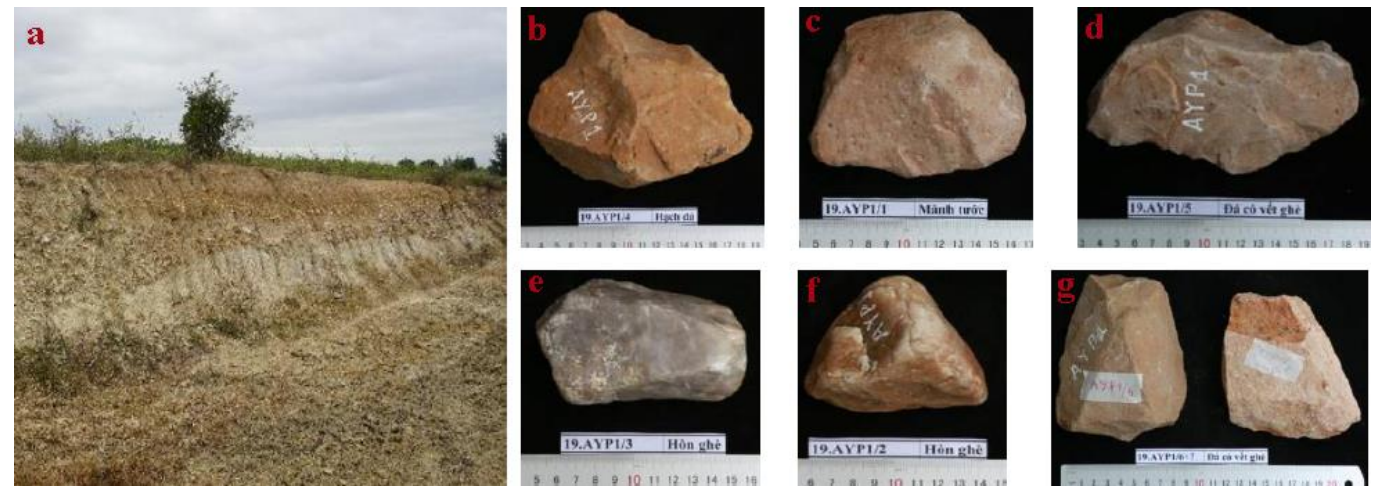

Hình 8. Vách thềm sông cổ bậc 2 (?) chứa di vật ở phường Cheo Reo (a) và hiện vật khảo cổ sưu tập tại thềm sông (b, c, d, e, f, g) (Nguồn: La Thế Phúc, 2020).

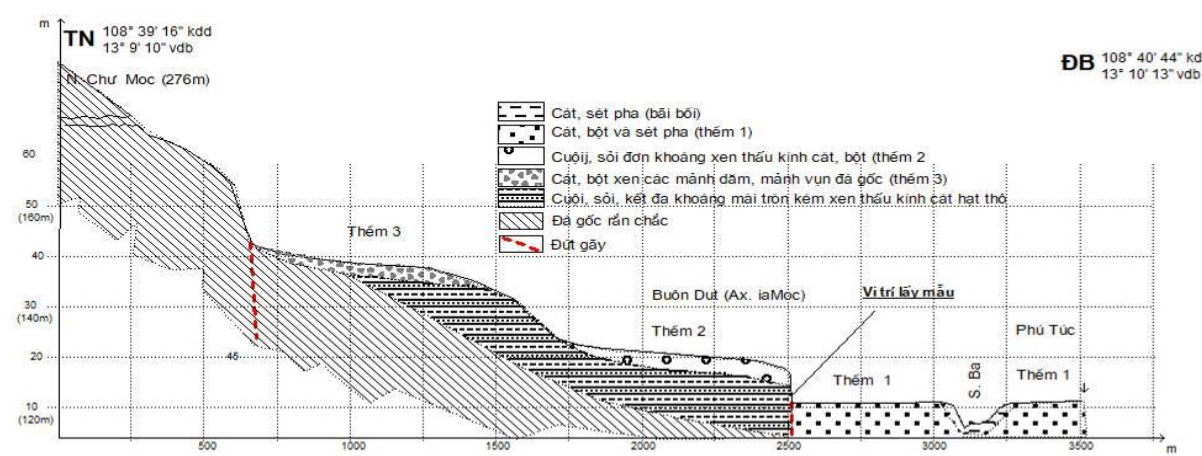

Hình 9. Mặt cắt địa chất - địa mạo khu vực Ia R’Mok - Phú Túc (huyện Krông Pa) và vị trí khảo sát lấy mẫu phát hiện di vật (người thành lập: Bùi Văn Thơm, 2019). 
- Loại hình di tích. Sự hiện diện của các công cụ đá, mảnh tước, phác vật, hạch đá, hòn ghè, đá có vết ghè, đá nguyên liệu v.v. với mật độ khá cao chứng tỏ các di tích Phú Thiện thuộc loại hình di tích cư trú và di tích công xưởng.

- Niên đại di tích. Thông qua các hội nghị hội thảo, kết hợp với công tác khảo sát thẩm định, so sánh với các khu vực khác trong và ngoài nước, các chuyên gia khảo cổ Việt Nam và Viện Khảo cổ \& Dân tộc học Novosibirsk (Nga) đã xếp cụm di tích Phú Thiện vào thời kỳ Đá cũ.

\subsection{Phát hiện di vật trên thềm sông cổ bậc $2 o^{\text {. }}$ phuòng Cheo Reo, thị xã A Yun Pa}

* Khảo sát phát hiện di vật: Trên cơ sở phân tích tài liệu bản đồ địa hình 1/50.000 của Chương trình Tây Nguyên, ảnh google map và kế thừa một số nguồn tài liệu khác, các tác giả đã nhận thấy khu vực $\mathrm{A}$ Yun Pa có 2 dấu hiệu dự báo cho tiềm năng có mặt những biểu hiện địa chất lý thú và tiềm năng di sản: i) Núi Chư Mố nằm đơn độc giữa đồng bằng phù sa của thung lũng sông $\mathrm{Ba}$ rất giống với địa hình miệng núi lửa; ii) Đặc điểm địa lý tự nhiên và địa chất Đệ tứ có nhiều nét tương đồng với khu vực Phú Thiện.

Trong đợt công tác tháng 11-12/2019, đoàn khảo sát địa chất La Thế Phúc, Bùi Văn Thơm cùng các cộng sự đã phát hiện được một số di vật đá của người tiền sử ở thềm cổ bậc 2 (?) của sông Ba trước kia (Hình 4).

\section{* So lược đặc điểm thành tạo địa chất chứa di vật}

Điểm lộ chứa di vật là vách của một ruộng lúa đã thu hoạch, tọa độ $13^{0} 24$ ' 42,4"vĩ độ Bắc, $108^{0} 22$ ' 43,4', kinh độ Đông. Vách cao 2 - 2,5m, dài $\sim 100 \mathrm{~m}$ theo hướng Đông Bắc- Tây Nam. Trầm tích của vách có màu xám sáng - xám vàng, đôi chỗ có các cành cây mục màu đen, nguồn gốc aluvi, tuổi Pleistocen giữa-muộn $(0,781-0,12$ ngàn năm $\mathrm{BP}$ ) [2]; được chia làm 2 phần (Hình 8a). Phần trên: dày $2 \mathrm{~m}$, gồm cát sạn ít khoáng chứa cuội. Cuội ít khoáng có độ mài tròn trung bình, phân bố thành 1-2 lớp không ổn định, dày từ $0,3-1,0 \mathrm{~m}$; thành phần chủ yếu là thạch anh, đá silic, cát bột kết. Các di vật được tìm thấy trong lớp cuội sạn ở phần trên này. Phần dưới phân bố độ sâu $>2$, gồm cát, chuyển dần xuống là cát bột sét, tại độ sâu >2,3-2,5m là bột, bột sét mà người dân san ủi làm đất trồng lúa và hoa màu, không có di vật.

\section{* So lược đặc điểm di vật}

Các di vật được tìm thấy trong lớp cuội sạn, gồm: hạch đá (Hình 8b), mảnh tước (Hình 8c), đá có vết ghè (Hình $8 \mathrm{~d}, 8 \mathrm{f}$ ), hòn ghè (Hình $8 \mathrm{e}$ ). Chất liệu những di vật này được làm từ thạch anh, đá silic, quartzit, cát kết dạng quartzit. Tuy chưa có những khảo sát đánh giá chi tiết, chuyên sâu tại điểm khảo sát này, nhưng đây chính là những phát hiện bước đầu, đánh dấu thêm một địa điểm rất cần được chú trọng để điều tra khảo sát kỹ hơn, nhằm làm sáng tỏ tiềm năng di tích ở khu vực này cũng như cho toàn khu vực thung lũng cổ Sông $B$.

3.5. Phát hiện di tích trên các thêm sông cổ ở Krông $\mathrm{Pa}$

\section{* Khảo sát phát hiện di tích}

Thung lũng Krông Pa là phần cuối của thung lũng sông Ba thuộc tỉnh Gia Lai trước khi chuyển sang đất Phú Yên. Nơi đây có các thành tạo trầm tích Neogen - Đệ tứ tương đồng với Phú Thiện (Hình 4). Dựa theo dấu hiệu tìm kiếm di tích Đá cũ đã được xác lập thì khu vực này rất có thể sẽ có mặt các di tích Đá cũ tương tự Phú Thiện.

Trong đợt công tác tháng 11-12/2019, đoàn khảo sát địa chất của đề tài TN17/T06 đã theo đường Trường Sơn Đông đi qua đây. Dọc theo đường này đi về phía núi (rìa Tây Nam) là những đồi thoải chứa cuội sạn và các vách thềm sông cổ bậc 2 (?) do người dân san ủi lấy đất làm đường. Tại khu vực này, La Thế Phúc, Bùi Văn Thơm, Lương Thị Tuất cùng các cộng sự đã phát hiện 3 điểm di tích Đá cũ tương đồng với cụm di tích Phú Thiện.

\section{* So lược đặc điểm địa chất của di tích}

- Nhóm thành tạo đá gốc truớc Đệ tú có 9 phân vị địa chất chủ yếu, bao gồm: các hệ tầng Đắk Lô (AR $d l)$ : gneis-biotit-silimanit-cordỉeitgranat; hệ tầng Mang Yang $\left(\mathrm{T}_{2} \mathrm{a} m y\right)$ : ryolit, felsit và tuf; hệ tầng Đray Linh $\left(\mathrm{J}_{1} d l\right)$ : cát bột kết, bột sét kết vôi; hệ tầng Đơn Dương $\left(\mathrm{K}_{2} d d\right)$ : dacit, ryođacit, ryolit, felsit, andesit và tuf; hệ tầng 
Sông $\mathrm{Ba}\left(\mathrm{N}_{1}^{3} s b\right)$ : cuội kết, cát sạn kết, bột sét kết và các phức hệ magma: Bến Giằng-Quế Sơn $\left(\gamma \delta \mathrm{PZ}_{3} b g-q s\right)$ : gabro diorit, granitoit, granit; phức hệ Vân Canh $\left(\gamma \delta \mathrm{T}_{2} v c\right)$ : diorit, granodorit, granit biotit; phức hệ Đèo Cả $(\gamma-\gamma \xi \mathrm{K} d c)$ : granit, granosyenit, granit biotit; phức hệ Cù Mông $(\gamma \pi \mathrm{E} \mathrm{cm})$ : gabrodiabas, diabas, porphyrit (Hình 4) [2]. Những thành tạo đá cổ này là nguồn cung cấp cuội sạn nguồn gốc eluvi, deluvi, proluvi, aluvi cho thung lũng Krông Pa mà đã được người tiền sử khai thác để chế tác công cụ.

- Nhóm thành tạo trầm tích bở rời Đệ túu có trầm tích Pleistocen sớm phần muộn $\left(\mathrm{aQ}^{1}{ }^{1.3}: 1,80\right.$ - 0,78 triệu năm BP) lộ khá phổ biến dọc theo rìa địa hình sườn đồi núi hai bên thung lũng Krông $\mathrm{Pa}$, phủ trực tiếp lên các thành tạo trầm tích hệ tầng Sông $\mathrm{Ba}\left(\mathrm{N}_{1}{ }^{3} s b\right)$. Thành phần trầm tích bao gồm cuội sạn sỏi đa khoáng ở phần trên; cát sạn - bột sét ở phần dưới. Cuội sỏi có độ mài tròn tốt - trung bình, đã phát hiện được nhiều công cụ đá, mảnh tước, hạch đá... của người tiền sử tương tự như Phú Thiện. Ngoài ra, ở đây còn có các thành tạo trầm tích tuổi Pleistocen giữa-muộn $\left(\mathrm{Q}_{1}{ }^{2-3}\right)$ và Holocen sớm-giữa $\left(\mathrm{Q}_{2}{ }^{1-2}\right)$ nguồn gốc sông (aluvi), phân bố dọc theo hai bờ sông suối của thung lũng Krông $\mathrm{Pa}$ (Hình 4). Các thành tạo trầm tích Đệ tứ không phân chia $(\mathrm{Q})$, nguồn gốc eluvi - deluvi - proluvi phân bố dọc theo các khe suối và sườn dốc của các núi đá gốc ven thung lũng. Đây cũng là đối tượng cần tìm kiếm trong quá trình điều tra chi tiết, đánh giá tiềm năng di tích Đá cũ ở khu vực này.

\section{* So lược đặc điểm di tích}

Do hạn chế về thời gian và kinh phí, nên công tác khảo sát của đoàn cán bộ khoa học thuộc đề tài TN17/T06 chỉ tiến hành dọc theo đường Trường Sơn Đông, thuộc dải Tây Nam của thung lũng Krông $\mathrm{Pa}$. Tại khu vực này, đoàn khảo sát đã phát hiện được 3 điểm có di vật đồ đá của người tiền sử, trong đó 2 điểm phân bố trên bề mặt các gò đồi là thềm cổ bậc 1 (ký hiệu $\mathrm{KP} 1$ và $\mathrm{KP} 3$ ) và 1 điểm trên vách của thềm cổ bậc 2 (ký hiệu KP2).

- Di tích KP1 trên thềm cổ bậc 1 (DSĐC phụ kiểu B1) của sông $B a$ (Hình 4, 10a), có tọa độ
$13^{0} 11$ '54,4" 'vĩ độ Bắc - $108^{0} 41$ ' 45.4' ' kinh độ Đông, độ cao tương đối $3-5 \mathrm{~m}$ ứng với thềm bậc 1; thuộc xã Ia HD'Reh, huyện Krông Pa (Hình 10a). Thềm có độ cao tương đối $3-5 \mathrm{~m}$, còn nguyên trạng. Cảnh quan địa mạo và trầm tích trên lớp mặt của thềm sông cổ chứa di vật ở đây là cuội sạn đa khoáng giống cụm di tích khu vực thung lũng Phú Thiện.

Các di vật công cụ đá tiền sử dễ dàng được tìm thấy ở đầy, bao gồm: công cụ đá (Hình $10 \mathrm{~b}$ ), mảnh tước ban đầu (Hình $10 \mathrm{c}$ ), đá có vết chế tác (Hình $10 \mathrm{~d}$ ) có chất liệu là đá quartzit; các đá nguyên liệu gồm thạch anh, đá silic, quartzit, ... Di tích này rất cần được điều tra nghiên cứu chi tiết để tiến hành khai quật, xây dựng bảo tàng bảo tồn tại chỗ phục vụ khai thác du lịch.

- Di tích KP2 trên thềm cổ bậc 2 (DSĐC phụ kiểu B1) của sông $B a$ (Hình 4, 9, 11a) có tọa độ $13^{0} 09^{\prime} 54.5^{\prime \prime}$ vĩ độ Bắc và $108^{\circ} 40^{\prime} 22.1^{\prime \prime}$ kinh độ Đông, độ cao tương đối $5-10 \mathrm{~m}$, thuộc buôn BLái, xã Ia R'Mok, huyện Krông Pa. Di tích nằm trên một gò đồi thoải là thềm sông cổ bậc 2 của sông $\mathrm{Ba}$ trước kia. Sườn đồi về phía Đông Bắc, cách đường Trường Sơn Đông khoảng $50-70 \mathrm{~m}$ đã bị xẻ để lấy đất san nền, làm đường, tạo ra vách taluy dốc đứng. Mặt cắt tại taluy này lộ ra tập trầm tích dày $4-5 \mathrm{~m}$, chia làm 2 phần rõ ràng: phần trên là cuội sạn đa khoáng, dày $2-3 \mathrm{~m}$; phần dưới là cát - bột - sét màu xám sáng, có dấu hiệu laterit hóa nhẹ ở phần trên (nơi tiếp giáp với phần cuội sạn) (Hình 11a).

Các di vật đá dễ dàng được tìm thấy ở phần đổ lở của lớp cuội sạn dưới chân taluy, bao gồm: công cụ chặt thô (Hình 11b), công cụ mảnh tước (Hình $11 \mathrm{c}$ ), mảnh tước, hòn ghè (Hình $11 \mathrm{~d})$ và hàng chục hạch đá (Hình 40), đá có vết ghè/chế tác; chất liệu hiện vật chủ yếu là thạch anh, quartzit, đá silic. Đặc trưng nhất của di vật phát hiện được tại điểm này là chúng có lớp patin rất dày (Hình $11 \mathrm{~b}, 11 \mathrm{c}, 11 \mathrm{e})$, nhiều khi không thể phân biệt được lớp patin của vết ghè với lớp patin của vỏ cuội. Đây là điểm rất đặc biệt và rất khác biệt so với di vật của các di tích khác ở Việt Nam, cần điều tra nghiên cứu chi tiết để xác định tiềm năng di tích và cơ chế thành tạo lớp patin dày của các di vật ở đây. 
- Di tích KP3 trên thềm cổ bậc 1 (DSĐC phu kiểu B1) của sông $B a$ (Hình 4, 12a) có tọa độ $13^{0}$ 06' 51.2" vĩ độ Bắc; $108^{0} 42^{\prime}$ 6.9" kinh độ Đông, thuộc Buôn Nai xã Ia HD’Reh, huyện Krông Pa. Di tích được phát hiện trên sườn gò đồi thấp thuộc thềm cổ bậc 1 của sông Ba trước kia. Thềm có độ cao tương đối 3-5m, giống với điểm KP1, còn nguyên trạng. Cảnh quan địa mạo và trầm tích trên lớp mặt chứa di vật ở đây là cuội sạn đa khoáng giống ở khu vực thung lũng Phú Thiện.
Các di vật dễ dàng được tìm thấy ở đây gồm: công cụ mũi nhọn tam diện (Hình 12b, 12c), công cụ mũi nhọn (Hình 12d), đá có vết ghè/vết chế tác (Hình 12e),... chất liệu là đá quartzit; đá nguyên liệu gồm thạch anh, đá silic, quartzit,... Di tích này cần được điều tra nghiên cứu chi tiết và có thể tiến hành khai quật, bảo tồn bảo tàng tại chỗ để khai thác du lịch và phát triển kinh tế xã hội.
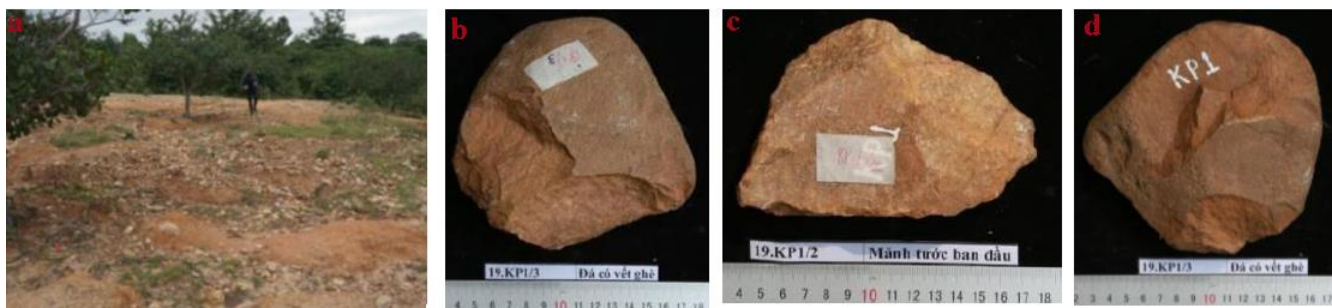

Hình 10. Gò đồi là thềm sông cổ bậc 1 chứa di vật (KP1) (a) và các hiện vật khảo cổ trên bề mặt $(b, c, d)$.
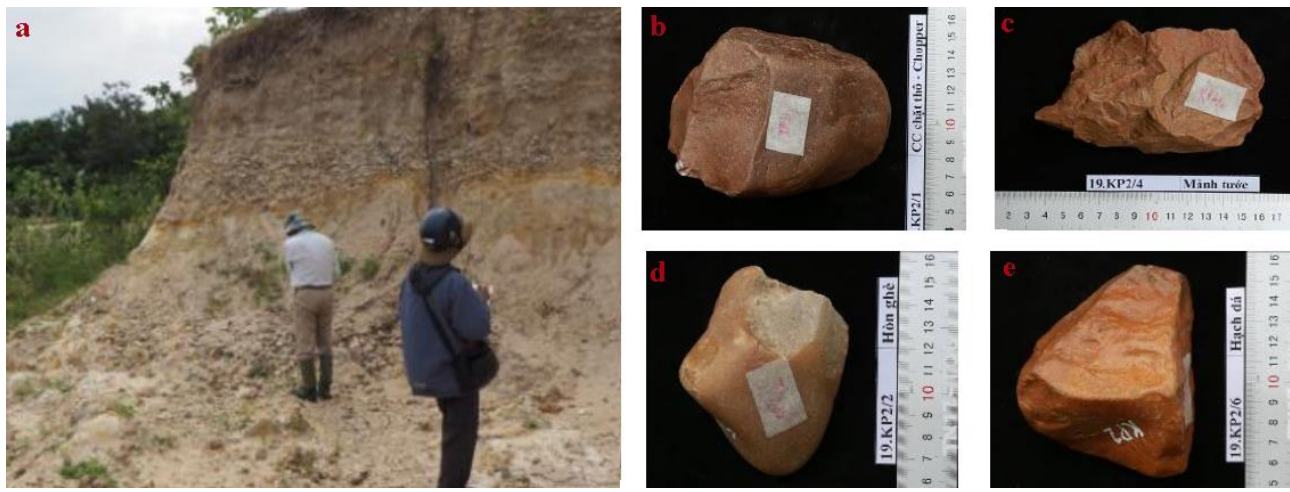

Hình 11. Vách thềm sông cổ bậc 2 chứa di vật (a) và hiện vật khảo cổ tại thềm sông cổ (b, c, d, e) (Nguồn: La Thế Phúc, 2019).
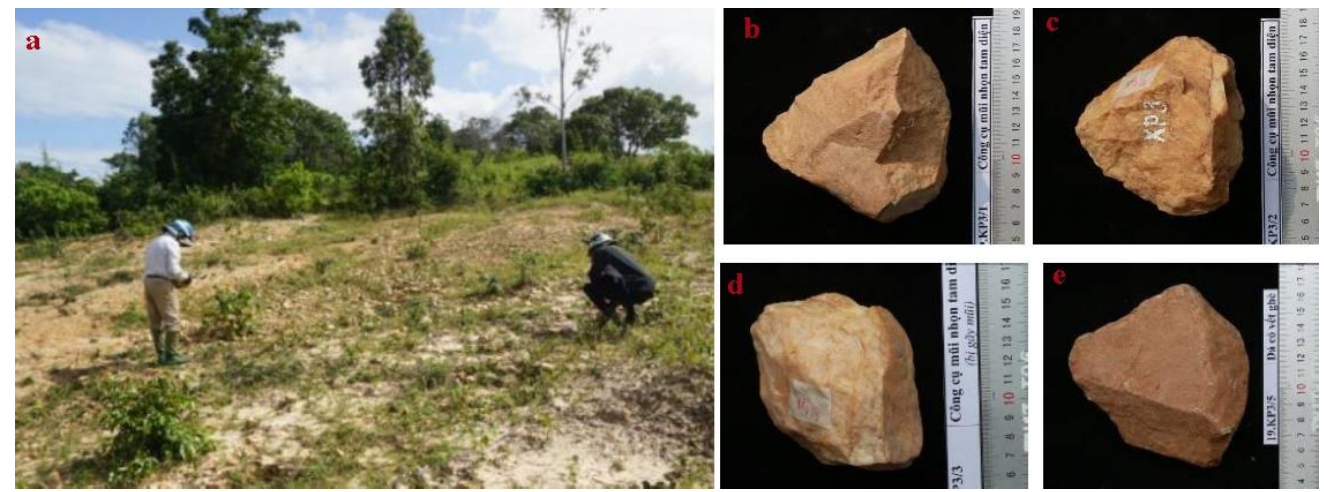

Hình 12. Thềm sông cổ bậc 1 chứa di vật (KP3) (a) và các hiện vật khảo cổ tại thềm sông cổ (Nguồn: La Thế Phúc, 2019). 


\section{Một số nhận xét và kiến nghị}

\subsection{Một số nhận xét}

* Đặc điểm phân bố di tích. Các di tích tiền sử phân bố rải rác trên diện rộng thuộc lưu vực sông Ba (Hình 1) trong mối liên quan mật thiết với các thành tạo địa chất và $\mathrm{DS} Đ C$ của khu vực và được phân chia thành 3 loại:

- Loại thứ nhất, phân bố ở khu vực các thác nước/hồ nước tự nhiên (DSĐC phụ kiểu $\mathrm{B} 1$ ) thuộc lưu vực sông $\mathrm{Ba}$ (tiêu biểu có Thác 50 và thác Hang Dơi ở huyện K'Bang; thác Phú Cường ở huyện Chư Sê; Biển Hồ ở Pleiku).

- Loại thứ hai, phân bố ở các sườn núi ở rìa thung lũng có độ cao tương đối $<100 \mathrm{~m}$, liên quan tới các thành tạo cuội sạn có nguồn gốc eluvi, deluvi, proluvi; tuổi Đệ tứ không phân chia (tiêu biểu có các sườn núi Chư $\mathrm{A}$ Thai, Đồn 1 , Đồn 2 : DSĐC phụ kiểu B1).

- Loại thứ ba, phân bố phổ biến ở các gò đồi thoải, thuộc các thềm sông cổ bậc 1 , bậc 2 , bậc 3 (DSĐC phụ kiểu B1) của sông Ba trước kia (tiêu biểu là hàng loạt di tích ở xã Chư $\mathrm{A}$ Thai, huyện Phú Thiện; phường Cheo Reo, thị xã $\mathrm{A}$ Yun $\mathrm{Pa}$; xã Ia R'Mok và Ia HD'Reh, huyện Krông Pa; xã Pờ Tó huyện Ia Pa; Gò Đá và Rộc Tưng ở An Khê).

* Đặc điểm hiện vật. Các hiện vật thu thập được bao gồm: công cụ chặt là rìu tay (handaxes), công cụ ghè một mặt (uni-face), công cụ ghè hai mặt (bi-face), công cụ chặt thô rìa dọc (end-chopper), công cụ chặt thô rìa ngang (side-chopper), công cụ hạch, mảnh tước, công cụ mảnh tước, hạch đá, hòn ghè, đá có vết ghè v.v. Chất liệu công cụ chủ yếu là các loại cuội thạch anh, đá silic, quartzit, đá sừng, opalchalcedon, gỗ hóa thạch (silic hóa) và một ít basalt, tất cả đều là nguồn nguyên liệu tại chỗ, là các di sản Đá (DSĐC kiểu D) của khu vực. Ghè đẽo là thủ pháp kỹ thuật được sử dụng để chế tác công cụ: vết ghè trực tiếp, thô sơ, tạo các rìa lưỡi sắc thẳng hoặc zig-zăc, mũi nhọn hoặc mũi nhọn tam diện. Phần lớn công cụ có trọng lượng lớn hơn nhiều so với các công cụ Đá mới, trên công cụ còn bảo lưu một phần vỏ cuội tự nhiên ở phần đốc/tay cầm. Điều này phản ánh trình độ chế tác và nhu cầu sử dụng còn rất sơ khai và đơn giản.
* Tính chất di tích. Hầu hết tại mỗi di tích đều tìm thấy các công cụ đá, mảnh tước, hạch đá có chất liệu giống với thành phần đá, cuội lộ ra tại di tích/di sản (nguyên liệu tại chỗ). Sự hiện diện của các công cụ cùng với các mảnh tước, hạch đá, hòn ghè, phác vật, đá nguyên liệu v.v. phản ánh loại hình di tích cư trú và di chỉ xưởng.

* Niên đại của di tích: trên cơ sở so sánh kích thước, loại hình học, kỹ thuật chế tác công cụ và sự thiếu vắng kỹ thuật mài... di tích được xác định thuộc thời kỳ Đá cũ.

* Giá trị các di sản mói phát hiện: Các di tích Đá cũ vừa được phát hiện có giá trị rất lớn cả về khoa học và thực tiễn:

- Thứ nhất: khẳng định sự xác thực về tính liên tục của dòng chảy lịch sử phát triển từ thời đại Đá cũ đến nay.

- Thứ hai: tăng thêm giá trị cho các DSĐC, di sản thiên nhiên. Các cảnh quan tự nhiên như: thác nước, hồ nước tự nhiên, miệng núi lửa (DSĐC phụ kiểu B1), các khu bảo tồn... khu vực sông Ba vốn đã rất đẹp, lại có thêm di tích cư trú của người tiền sử được bảo tồn và phục dựng tại chỗ sẽ là điểm nhấn đặc biệt thu hút du lịch. Các di sản đá (DSĐC kiểu D) của khu vực được bổ sung giá trị di sản văn hóa/khảo cổ khi chúng chính là nguồn nguyên liệu đã từng được người tiền sử dùng để chế tác công cụ.

- Thứ ba: cung cấp tài nguyên vô giá cho cho các hoạt động khai thác các giá trị đa dạng của di sản, phát triển bền vững kinh tế xã hội.

* Hiện trạng bảo tồn di tích: Rất đáng tiếc là hiện nay các di tích khảo cổ cùng với các DSĐC kiểu $\mathrm{B} 1$ chứa chúng dọc thung lũng sông $\mathrm{Ba}$ đang đứng trước nguy cơ bị xâm hại và phá hủy một cách vô tình do các hoạt động nhân sinh: san ủi lấy đất làm đường hoặc tạo mặt bằng để canh tác nông nghiệp. Các di vật khảo cổ quý giá chưa được bảo vệ, bảo tồn nên đã và đang bị thu gom để bán,... Vì vậy, ngay sau khi phát hiện được di tích, tác giả đã lập tức báo cáo với các cấp chính quyền địa phương và đã đề nghị các cấp có thẩm quyền và các cơ quan chức năng cần hành động kịp thời, đưa ra các giải pháp hữu hiệu để bảo tồn khẩn cấp các di sản hỗn hợp rất có giá trị này. 


\subsection{Một vài kiến nghị}

- Cần bảo vệ bảo tồn khẩn cấp các khu vực phân bố các di sản hỗn hợp, các di tích khảo cổ đã được phát hiện nêu trên. Cụ thể: cần giữ nguyên hiện trạng tự nhiên của các thác nước, hồ nước, các diện phân bố cuội sạn sỏi đa khoáng ở sườn và thềm thung lũng cổ sồng $\mathrm{Ba}$, nhằm triển khai các công tác nghiên cứu bảo tồn bảo tàng tiếp theo.

- Cần khẩn trương điều tra nghiên cứu theo diện rộng và chuyên sâu toàn bộ khu vực thung lũng cổ sông $\mathrm{Ba}$ nhằm: i) Khoanh định đầy đủ các diện phân bố di tích/di sản; ii) Đánh giá tiềm năng di tích/di sản; ii) Lựa chọn các vị trí khai quật theo hướng bảo tồn bảo tàng tại chỗ, khai thác du lịch, phát triển bền vững kinh tế xã hội.

- Cần sớm triển khai các phương pháp nghiên cứu chuyên sâu nhằm xác lập văn hóa khảo cổ "Văn hóa Sông $B a$ " thời đại Sơ kỳ Đá cũ mà xuất phát điểm là hệ thống các di tích Đá cũ đã được đề tài TN17/T06 phát hiện.

- Cần tăng cường hợp tác liên ngành, kêu gọi đầu tư nghiên cứu trong và ngoài nước nhằm sớm làm rõ tiềm năng và khai thác tiềm năng di sản đới sông $\mathrm{Ba}$ cho sự phát triển bền vững.

- Cần sớm công nhận các điểm di tích khảo cổ mới được phát hiện trong mối liên quan/gắn bó chặt chẽ với các DSTN, DSĐC dưới dạng các di sản hỗn hợp để bảo tồn khẩn cấp, đẩy mạnh công tác tuyên truyền, giáo dục nâng cao nhận thức cộng đồng trong công cuộc bảo tồn di tích/di sản nói chung và di tích/di sản ở khu vực thung lũng sông Ba nói riêng.

Bài viết là kết quả khảo sát thực địa của đề tài KHCN cấp Nhà nước mã số TN17/T06 và đề tài cấp cơ sở "Điều tra tìm kiếm di chi khảo cổ khu vục Chu A Thai, huyện Phú Thiện, tỉnh Gia Lai".

\section{Tài liệu tham khảo}

[1] T.V. Tri, V. Khuc. Geology and natural resources of Vietnam. Publishing House of Natural Science and Technology, Vietnam, 2009, 589p (in Vietnamese).
[2] T. Tinh. Geology and Mineral Map of An Khe, scale 1:200.000. Center for Information and Archives of Geology, General Department of Geology and Minerals of Vietnam, Hanoi, 1996 (in Vietnamese).

[3] T.H. Phuong, T.Q. Hai, D.V. Bao. Some natural heritages of outstanding values for tourism development in Central Highland. Vietnam Journal of Earth Sciences 37 (2) (2015) 182-192, http://www.vjs.ac.vn.index.php/jse (in Vietnamese).

[4] T.Q. Hai. Tourism in The Central Highlands: Scientific basis and development solutions. Hanoi National University Publishing House, 2018, 782p. (in Vietnamese).

[5] L.T. Phuc, N.K. Su, L.T. Tuat, V.T. Duc, B.V. Thom, N.T. Minh. Some new heritage discoveries in The Central Highlands, Vietnam. VNU Journal of Science: Earth and Environmental Sciences 36(1) (2020) 79-92. https://doi.org/10.25073/2588 1094/vnuees.4565 (in Vietnamese).

[6] N.K. Su. Gia Lai prehistory. Department of Culture and Information of Gia Lai province, Pleiku, 1995, 220p., (in Vietnamese).

[7] N.K. Su. Prehistoric archaeology in Central Vietnam. Social Sciences Publishing House, Hanoi, 2016, 782p. (in Vietnamese).

[8] N.T.K. Van. Gia Lai- From the origin to 1975. Social Sciences Publishing House, Hanoi, 2019, 792p. (in Vietnamese).

[9] N.G. Doi, N.K. Su. System of the Paleolithic Locations in the Upper Ba River. Vietnam Social Sciences 4 (168) (2015) (in Vietnamese).

[10] Ng.K. Su. An Khe Early Paleolithic techniques and Vietnam primitive history. Archaeology Journal, Hanoi 2 (2017) 3-18 (in Vietnamese).

[11] A.P. Derevianko, A.V. Kandyba, N.K. Su, S.A. Gladyshev, N.G. Doi, V.A. Lebedev, A.M. Chekha, A.G. Rybalko, V.M. Kharevic, A.A.Tsybankov. The discovery of a Bifacial Industry in Vietnam, in Archaeology, Ethnology \&Anthropology of Eurasia 3 (46) (2018) 3-21.

[12] L.T. Phuc, N.K. Su, V.T. Duc, L.T. Tuat, P.T. Toan, N.T. Tung, N.T. Minh. New discovery of prehistoric archaeological remnants in volcanic caves in Krongno, Dak Nong Province, Vietnam Journal of Earth Sciences, Vietnam Academy of Science and Technology, Hanoi 39 (2) (2017) 97 108. https://doi.org/10. 15625/0866-7187/39/2/9186. 